\title{
MJN \\ E-LEARNING: PROBLEMS AND STRATEGIES OF IMPROVEMENTS FROM THE FACULTY STUDENTS POINTS OF VIEW
}

\author{
Eman Abd Elalim Etway \\ Faculty of Nursing, Cairo University, Egypt \\ *Corresponding Author's Email:emabdalim@yahoo.com
}

\begin{abstract}
Background: E-learning has become important in higher education organization to enhance their educational provision. Although e-learning had made learning flexible, but it had brought numerous problems, including how to give and receive feedback, issues of role models, recognition, administrative system, human aspect of training, and bringing together the community of learners. Aim: Assess the e-learning: problems and strategies of improvements from the faculty students' points of view. Design: Descriptive design was used in this study. Subject: Convenient sample of senior students $(n=170)$ who had been exposed to electronic courses. Setting: At Accredited faculty of nursing, Cairo University. Tools: Two questionnaires were developed and used for data collection; Problems of e-learning (42 items) and Strategies of improvements of problems (10 items). Results: The findings of the present study conclude that nursing students were highly perceived e-learning system problems (Mean\%=78.26) followed by $(77.95 \%, 67.08 \%)$ for the problems related to the administrative system and the problems related to the academic staff respectively and the highly perceived (Mean $\%=63.5 \%$ ), also the best strategies of improvements were regarding offering training courses for faculty members and students on how to use e-learning and establishing a stable system for the periodic maintenance of computers, headsets, and laboratory tools. Conclusion: The finding of this present study concludes that the nursing students found the e-learning system problems was on the top of the problems and the best strategies of improvements from students' perspectives were offering training courses for faculty members and students. Recommendations: Faculty administration should design intensive training program to faculty staff and nursing students to improve their competences about e-learning system, improving the infrastructure and its technical equipments in order to create the right conditions for teachers in teaching, preparing professional technical staff to maintain electronic equipment, infrastructure and support user.
\end{abstract}

Keywords: E-Learning; Problems; Strategies of Improvements; Students

\section{INTRODUCTION}

Technological changes, particularly web-based elearning technologies, have resulted in new curriculum design and teaching strategies, new and emerging organizational structures and its even transformed the aspect of learning (Chapman, 2012; Donahue \& Glodstein, 2013). Contends that technology would transform the act of teaching, whether lecturers or students are ready for this inevitable change is matter of concern. E-learning is true in the fact that technology is here to reshape current learning systems and academic institutions by offering students new ways of seeing and learning; giving lecturers in new ways of teaching and imparting knowledge; and administrators are organizing new ways of learning management systems (Macharia $\&$ Pelser, 2014). New ways of tuition and of trying to seek out and retrieving information are developed. So, substantial changes have occurred as a result of elearning (Yamani, 2014).

With the rapid development of information communication technologies (ICT), internet technologies and web-based applications have created unprecedented chances for conducting learning (Cheng, 2011; Pourghaznein et al., 2015). E-learning is one method of delivering 'online' instruction and relates to web/ computer-based programs and virtual learning 
environments (Barker et al., 2013). In other words, eLearning is learning utilizing electronic technologies to access educational curriculum outside of a traditional classroom. In most cases, it refers to a course, program or degree delivered completely online. Also given the opportunities that online education provides for faculty, students and institutions, the amount of attention it received, isn't surprising (Yom, 2014; Assareha \& Hosseini Bidokht, 2016; Othman, 2016).

E-learning and E-teaching are still to grow at the tremendous rate. E-learning companies are developing everywhere (Williams, 2013). The field is growing at a tremendous rate and its standards have yet to be developed or perhaps arranged (Nhoun, Bhuasiri \& Rho 2012). E-learning may be understood as any sort of learning delivered electronically. Defined broadly, this could encompass learning products delivered by computer, intranet, internet, satellite, or other remote technologies (Sayed \& Baker, 2014). Assareha \& Hosseini, (2016) defined e-Learning term as, innovative approach to education delivery via electronic forms of information that enhance the students' skills, knowledge, or other learning performance.

Integration of ICT competency into a nursing curriculum is vital to confirm success throughout the education and career of latest nursing students. As enrolment in nursing programs increases, the varied population of students from many various cultural and socioeconomic backgrounds presents a challenge for faculty in addressing unique learning needs (Edwards \& Connor, 2014). Since 2000, the growths in e-learning, blended approaches that mixes online and face to-face training, has exploded (Hogan \& Kedrayate 2015). Elearning may be a commonplace in nursing and healthcare professional education Koch (2014) O'Malley, B. (2007), and usually the importance of Information and Communication Technology (ICT) and the internet in tertiary education is recognized (Button, Harrington \& Belan, 2016). As a result, in nursing education both teachers and nursing students are being expected to include and use digital technologies to facilitate learning in undergraduate nursing curricula (Njenga \& Fourie, 2017).

Masoumi \& Lindstrom (2012); Rasem (2013) show that e-learning benefits many folks because it is accessible 24 hours every day and from anywhere within the globe, e-learning provides greater flexibility of access Mayer et al., (2015) and is actually a web- based system that makes information or knowledge available to students and disregards time limitations or geographic proximity (Pettersson \& Olofsson, 2015). Furthermore, Tarhini, Teo \& Tarhini (2016) agree that e-learning promotes flexibility and pace of study, where students are able to work for as long as they need to on the online activities. Egan \& Akdere (2004) stated that the e-learning system is successful as the system is important to encourage student learning leading to a better level of student engagement (Macharia \& Pelser, 2012; Allen \& Seaman, 2014). E-learning will be better than face-to-face learning, the standard of interaction and timely feedback is superior, with good course design, can untangle the geographical limitations to education (Chen \& Yang, 2014).

Nyerere \& Gravenir (2016); Keengwe \& Kidd (2017) identified the subsequent as factors that impact on e-learning: lectures' attitudes and teaching styles, student motivation, student technical competency, student-student interaction, easy access to the technology, infrastructure reliability and lack of support at the postsecondary level. However, Sangra, Vlachopoulos \& Cabrera (2018) found the subsequent factors as prohibitive to the effective use of technology or ICT: (a) some older lecturers were at risk of teaching as they were use to traditional means; (b) novice lecturers with limited training were less likely to use the technology; (c) the amount of time required to develop and maintain an e-learning course (d) an absence of accessible professional development; and (e) an occasional level of contact between teachers and students who have little experience using technology (f) e-learning is expensive to access information because it requires an on line connection, computers and other devices for communication (Opeyemi et al., 2019).

While the worth of e-learning lies in its ability to coach anyone, anytime, anywhere, implementing and sustaining e-learning programs require merely to moving education and learning online (Lakbala, 2016). Also, if we are to develop, deliver and administer elearning programs, and train educators to become competent e-learning facilitators, a high level of investment in ICT infrastructure is required. Successful e-learning implementation therefore depends on building a technique that meets the requirements of the learners and also the business goals of the institution like implement the e-learning platform (Anderson, 2018). 


\section{Significance}

From the investigator point of view it was noticed that despite the importance and benefits of e-learning especially within the current situation of confinement at homes, e-learning emerge as a mandatory strategy to manage the emergency situation as a start point to continue within the future. Therefore, this experience requires extensive exploration of its benefits and problems from students and user perspectives in an attempt to enhance benefits in addition to discovering and solving problems. Consequently, this study assesses the problems of e-learning and strategies of improvements from the nursing students' points of view.

\section{Subjects and Methods}

Aim: The present study was conducted to assess the problems of e-learning and strategies of improvements from the nursing students' points of view.

Design: Descriptive design was utilized during this study.

\section{Research questions}

- What are the problems of e-learning from the nursing students' point of view?

- What are the strategies of improvements for managing theses problems from the nursing students' points of view?

\section{Study setting}

This study was carried out at accredited faculty of nursing, Cairo University.

\section{Subject}

A convenient sample of nursing students (170) out of 185 students were selected based on the inclusion criteria, were enrolled in fourth level because those group had been exposed to electronic courses for at least 2 successive years, actively enrolled within the two semesters of academic year 2018-2019 and comply with participation of the study.

\section{Tools}

Two tools were developed by El-Hersh, Muflih \& Aldhoon (2010); Jette et al., (2010) and modified by the investigator to gather data for the present study:

1. Problems of e-learning questionnaire from faculty student's point of view. It comprises of two parts: The first part includes the personal data of faculty students as gender, age, and attending e-learning courses.
The second part used to investigate the problems of elearning from faculty students' point of view. It consists of 42 items of problems divided into 13 items associated with the administrative system, 12 items associated with academic staff and 7 items associated with electronic learning system.

2. Strategies of improvements of problems questionnaire used to assess ways of managing problems associated with applying of e-learning courses from faculty students' point of view. It consists of 10 items associated with managing problems related to applying of e-learning courses.

The items of two questionnaires were rated on a 3points Likert scale, extending from one (No) to three (Yes). Total scores of studied responses concerning elearning problems classified as follow; low $<66 \%$, moderate $66-75 \%$, and high $>75 \%$ of the full scores.

\section{Tools validity and reliability}

The two tools contents were developed and tested for its content validity through five experts from nursing administration department, faculty of nursing, Cairo University. Within the light of their recommendations the important adjustments were produced. Double translation English-Arabic-English was done to confirm validity of translation.

Test of reliability for the e-learning problems questionnaire Cronbach's Alpha Coefficient, it showed 0.97 during pilot study. Also, reliability test for strategies of improvements questionnaire 0.87. This indicated that two questionnaires are highly reliable.

\section{Pilot study}

A pilot study was carried out on a sample of $10 \%$ of the students. A total of 17 students were engaged before starting the particular data collection to establish the clarity, and applicability of the study tools. It also aided the estimation of the time necessary to fill in those questionnaires. In view of the outcomes of the pilot study, modifications, clarifications, omissions, and rearrangement of some questions were done. Pilot study was not included within the study.

\section{Ethical consideration}

Official permissions were obtained from vice dean of students affairs at faculty of nursing, Cairo University to conduct the study. Oral acceptance was taken from all participants included within the study. The nature and 
the aim of the study were explained to all students before starting the data collection. Confidentiality of obtained data was assured.

\section{Procedure}

Once permission was granted from the faculty vice dean of students affairs the aim of the study was explained to faculty students who agreed to participate in the study. The respondents were assured for complete confidentiality. An explanation of each tool was done before giving them to the respondent on their classes and was filled out within a time range of half-hour. Data was collected during 2019-2020 year within a period of three months beginning from December 2019 to the end of February 2020 . The problems were measured by faculty students' points of view, then it was analyzed by strategies of improvements for managing problems that were developed during application e-learning courses and measured by the faculty students' point of view.

\section{Statistical Analysis}

Data entry and statistical analysis were done using Statistical Package for Social Science (SPSS), version 21.0. The subsequent descriptive statistics were used: frequencies, arithmetic mean: as average describing the central tendency of perception. The standard deviation: as a measure for scattering for outcomes around the mean (for quantitative variables). For comparison between more than two means, the $F$ value of analysis of variance (ANOVA) was computed. Significance was adopted at $p<0.05$ for interpretation of test results for significance.

\section{RESULTS}

Table 1: Frequency and Percentage Distribution of Students According to their Personal Characteristics $(n=170)$

\begin{tabular}{|l|c|c|}
\hline Items & No. & \% \\
\hline Gender & 64 & 37.6 \\
\hline Male & 106 & 62.4 \\
\hline Female & 18 & 10.6 \\
\hline Age & 145 & 85.3 \\
\hline$<20$ years & 7 & 4.1 \\
\hline $20<25$ years & 150 & 88.2 \\
\hline $25<30$ years & 20 & 11.8 \\
\hline Attending e-learning courses & \\
\hline Yes & \multicolumn{2}{|l|}{} \\
\hline No &
\end{tabular}

Table 1 depicts the frequency and percentage distribution of students according to their personal data, with regard to the gender $62.4 \%$ were female, $85.3 \%$ were in the age group ranged between $20<25$ years, $88.2 \%$ were attending e-learning course.

Table 2: Mean Percentage of Student's Point of view of Related E-learning Problems $(n=170)$

\begin{tabular}{|l|c|c|c|c|c|}
\hline Dimensions & Minimum & Maximum & Mean & $\begin{array}{c}\text { Std. } \\
\text { Deviation }\end{array}$ & $\begin{array}{c}\text { Mean } \\
\%\end{array}$ \\
\hline $\begin{array}{l}\text { Problems related to } \\
\text { the e-learning } \\
\text { system }\end{array}$ & 7.00 & 21.00 & 16.4 & 3.2 & 78.26 \\
\hline $\begin{array}{l}\text { Problems related to } \\
\text { the administrative } \\
\text { system }\end{array}$ & 17.00 & 39.00 & 30.4 & 5.0 & 77.95 \\
\hline $\begin{array}{l}\text { Problems related to } \\
\text { the academic staff }\end{array}$ & 12.00 & 36.00 & 24.1 & 5.2 & 67.08 \\
\hline $\begin{array}{l}\text { Total perception } \\
\text { regarding problems }\end{array}$ & 36 & 96 & 70.9 & 13.3 & 73.94 \\
\hline
\end{tabular}

Table 2 displays that total perception of students regarding problems $(73.94 \%)$. The highest mean percent were $78.26 \%$, for the problem related to the elearning system followed by $77.95 \%, 67.08 \%$ for the problems related to the administrative system and for the problems related to the academic staff respectively.

Table 3: Percentage Distribution of Student's Point of view of E-learning Problems Related to the E-learning $\operatorname{System}(n=170)$

\begin{tabular}{|l|c|c|c|c|c|c|}
\hline \multirow{2}{*}{$\begin{array}{l}\text { Problems related to the E - } \\
\text { learning system }\end{array}$} & No & \multicolumn{2}{l|}{$\begin{array}{c}\text { To some } \\
\text { extent }\end{array}$} & \multicolumn{2}{|l|}{ Yes } \\
\cline { 2 - 7 } & No. & No. & $\%$ & No. & $\%$ \\
\hline $\begin{array}{l}\text { The lack of clarity of the e- } \\
\text { learning philosophy and its goals }\end{array}$ & 35 & 20.6 & 64 & 37.6 & 71 & 41.8 \\
\hline $\begin{array}{l}\text { The high cost of preparing good } \\
\text { software }\end{array}$ & 15 & 8.8 & 58 & 34.1 & 97 & 57.1 \\
\hline $\begin{array}{l}\text { The difficulty of applying } \\
\text { learning in some courses that } \\
\text { require practical skills }\end{array}$ & 15 & 8.8 & 68 & 40 & 87 & 51.2 \\
\hline $\begin{array}{l}\text { Weak interaction between the } \\
\text { lecturer and the learner }\end{array}$ & 23 & 13.5 & 61 & 35.9 & 86 & 50.6 \\
\hline $\begin{array}{l}\text { The lack of specialists in } \\
\text { designing educational materials } \\
\text { capable of e-learning }\end{array}$ & 14 & 8.2 & 75 & 44.1 & 81 & 47.6 \\
\hline $\begin{array}{l}\text { It does not focus on all the senses, } \\
\text { so it is not suitable in some } \\
\text { practical applications }\end{array}$ & 26 & 15.3 & 67 & 39.4 & 77 & 45.3 \\
\hline $\begin{array}{l}\text { The procedures for producing } \\
\text { electronic courses are long } \\
\text { administrative and technical } \\
\text { process. }\end{array}$ & 26 & 15.3 & 75 & 44.1 & 69 & 40.6 \\
\hline
\end{tabular}

Table 3 displays that more than half of the participants $(57.1 \%, 51.2 \%)$ had perceived for the high cost of preparing good software in the e-learning style and the difficulty of applying-learning in some courses that require practical skills respectively. Also $8.2 \%$ of the participants had not perceived for the lack of specialists in designing educational materials capable of e-learning item. 
Table 4: Percentage Distribution of Students' Point of View of E-Learning Problems Related to The Administrative System

\begin{tabular}{|c|c|c|c|c|c|c|}
\hline \multirow{2}{*}{ Problems related to the administrative system } & \multicolumn{2}{|c|}{ No } & \multicolumn{2}{|c|}{ To some extent } & \multicolumn{2}{|c|}{ Yes } \\
\hline & No. & $\%$ & No. & $\%$ & No. & $\%$ \\
\hline $\begin{array}{l}\text { Lack of equipment for the halls with modern tools and equipment needed for e- } \\
\text { learning }\end{array}$ & 19 & 11.2 & 71 & 41.8 & 80 & 47.1 \\
\hline Failure to train faculty staff to use e-learning & 53 & 31.2 & 77 & 45.3 & 40 & 23.5 \\
\hline $\begin{array}{l}\text { Lack of cooperation between universities in exchanging experiences and } \\
\text { knowledge in the field of e-learning }\end{array}$ & 38 & 22.4 & 70 & 41.2 & 62 & 36.5 \\
\hline Lack of financial resources allocated to e-learning programs & 21 & 12.4 & 67 & 39.4 & 82 & 48.2 \\
\hline Poor infrastructure in good connectivity & 31 & 18.2 & 74 & 43.5 & 65 & 38.2 \\
\hline Lack of Internet service on an ongoing basis & 22 & 12.9 & 52 & 30.6 & 96 & 56.5 \\
\hline Frequent interruption of internet service while using in the e-learning process & 20 & 11.8 & 61 & 35.9 & 89 & 52.4 \\
\hline The shortage of maintenance services for devices periodically & 14 & 8.2 & 59 & 34.7 & 97 & 57.1 \\
\hline Insufficient number of computers for students & 9 & 5.3 & 40 & 23.5 & 121 & 71.2 \\
\hline Lack of computer labs in proportion to the number of students & 11 & 6.5 & 43 & 25.3 & 116 & 68.0 \\
\hline Increasing the academic burden on a faculty member & 22 & 12.9 & 84 & 49.4 & 64 & 37.6 \\
\hline Lack of clarity in the objectives of using the e-learning system & 46 & 27.1 & 72 & 42.4 & 52 & 30.6 \\
\hline Limited availability of specialized technicians to solve technical pro & 10 & 5.9 & 60 & 35.3 & 100 & 58.8 \\
\hline
\end{tabular}

This table showed that the highest percentage $(71.0 \%$, $68.0 \%$ ) of the students perceived 'lack of computers in sufficient numbers for students' followed by 'lack of computer labs in proportion to the number of students that learn electronically' while lowest percentage $(23.5 \%)$ was regarding failure to train faculty staff to use e-learning.

Table 5: Percentage Distribution of Students'Point of view of E-learning Problems Related to the Academic Staff $(n=170)$

\begin{tabular}{|c|c|c|c|c|c|c|}
\hline \multirow{2}{*}{ Problems related to the academic staff } & \multicolumn{2}{|c|}{ No } & \multicolumn{2}{|c|}{ To some extent } & \multicolumn{2}{|c|}{ Yes } \\
\hline & No. & $\%$ & No. & $\%$ & No. & $\%$ \\
\hline Lack of faculty members who master the technological skills required for e-learning & 27 & 15.9 & 84 & 49.4 & 59 & 34.7 \\
\hline $\begin{array}{l}\text { Faculty members feel that e-learning diminishes the authority and control over the } \\
\text { course of the educational process }\end{array}$ & 57 & 33.5 & 72 & 42.4 & 41 & 24.1 \\
\hline $\begin{array}{l}\text { E-learning weakens students' faith in the educational trends and values that the } \\
\text { university is working to equip them with }\end{array}$ & 59 & 34.7 & 75 & 44.1 & 36 & 21.2 \\
\hline Non-response of faculty members to the new style of learning & 57 & 33.5 & 28 & 16.5 & 85 & 50 \\
\hline Not being convinced of the importance of using e-learning in teaching courses. & 62 & 36.5 & 80 & 47.1 & 28 & 16.5 \\
\hline Lack of information and technological skills required for e-learning & 39 & 22.9 & 68 & 40 & 63 & 37.1 \\
\hline E-learning represents an additional burden over the workload assigned to them & 50 & 29.4 & 82 & 48.2 & 38 & 22.4 \\
\hline Lack of ability and competence among faculty members to use e-learning. & 47 & 27.6 & 84 & 49.4 & 39 & 22.9 \\
\hline $\begin{array}{l}\text { Feeling that electronic education lacks confidentiality and safety regarding the } \\
\text { content and exams }\end{array}$ & 56 & 32.9 & 68 & 40 & 46 & 27.1 \\
\hline Low degree of social interaction between student and faculty member & 33 & 19.4 & 79 & 46.5 & 58 & 34.1 \\
\hline Difficulty following students individually & 24 & 14.1 & 66 & 38.8 & 80 & 47.1 \\
\hline The negative trend of faculty members towards the e-learning system & 40 & 23.5 & 70 & 41.2 & 60 & 35.3 \\
\hline
\end{tabular}

Table 5 Illustrates that around half of the participants $(50 \%)$ had perceived for the item nonresponse of faculty members to the new style of learning. On the opposite least percent $(14.1 \%)$ not perceived for the item 'difficulty following students individually. 
Table 6: Percentage Distribution of Students' Point of View Related To The Strategies of Improvement of ELearning Problems $(\mathrm{N}=170)$

\begin{tabular}{|c|c|c|c|c|c|c|}
\hline \multirow{2}{*}{ Strategies of improvement } & \multicolumn{2}{|c|}{ No } & \multicolumn{2}{|c|}{ To some extent } & \multicolumn{2}{|c|}{ Yes } \\
\hline & No. & $\%$ & No. & $\%$ & No. & $\%$ \\
\hline $\begin{array}{l}\text { Offering training courses for faculty members and students on how to use e- } \\
\text { learning }\end{array}$ & 12 & 7.1 & 50 & 29.4 & 108 & 63.5 \\
\hline $\begin{array}{l}\text { Training of specialized members of faculty members to supervise the } \\
\text { application of the use of e-learning }\end{array}$ & 16 & 9.4 & 63 & 37.1 & 91 & 53.5 \\
\hline $\begin{array}{l}\text { Developing and increasing students' awareness of the importance of e- } \\
\text { learning }\end{array}$ & 17 & 10 & 57 & 33.5 & 96 & 56.5 \\
\hline $\begin{array}{l}\text { Providing a sufficient number of laboratories equipped with sufficient } \\
\text { computers to teach students }\end{array}$ & 24 & 14.2 & 48 & 28.2 & 98 & 57.6 \\
\hline Improve the internet throughout the day & 16 & 9.4 & 53 & 31.2 & 101 & 59.4 \\
\hline Encouraging faculty members to produce electronic courses & 22 & 12.9 & 56 & 32.9 & 92 & 54.1 \\
\hline $\begin{array}{l}\text { Providing support and motivation from the college and university } \\
\text { administration for faculty members participating in e-learning }\end{array}$ & 22 & 12.9 & 47 & 27.6 & 101 & 59.4 \\
\hline E-learning application in all specialized nursing courses & 30 & 17.6 & 46 & 27.1 & 94 & 55.3 \\
\hline $\begin{array}{l}\text { Training technical members to participate in solving technical problems } \\
\text { during the application of e-learning }\end{array}$ & 19 & 11.2 & 48 & 28.2 & 103 & 60.6 \\
\hline $\begin{array}{l}\text { Establishing a stable system for the periodic maintenance of computers, } \\
\text { headsets, and laboratory tools }\end{array}$ & 21 & 12.4 & 41 & 24.1 & 108 & 63.5 \\
\hline
\end{tabular}

Table 6 displays that around two thirds of the participants had perceived all items of related to the suggested improvement of e-learning problems. The same table showed that the highest percent related suggested improvement $(63.5 \%)$ for the items holding training courses for faculty members and students on how to use e-learning and establishing a stable system for the periodic maintenance of computers, headsets, and laboratory tools followed by $60.6 \%$ for training technical cadres to participate in solving technical problems during the application of e-learning.

Table 7: Relationship Between Total Students' Point of View Regarding E-learning Problems, Strategies of Improvement and Personal Data (n=170)

\begin{tabular}{|l|c|c|c|c|}
\hline \multirow{2}{*}{ Personal data } & \multicolumn{2}{|c|}{ Total perception regarding problems } & \multicolumn{2}{c|}{ Total perception regarding strategies of improvement t } \\
\cline { 2 - 5 } & Test result & $\boldsymbol{p}$ & Test result & $\boldsymbol{p}$ \\
\hline Gender & $2.24^{*}$ & 0.59 & $0.18^{*}$ & 0.70 \\
\hline Age & $6.55^{* *}$ & 0.002 & $8.327^{* *}$ & 0.000 \\
\hline Attending e-learning courses & $1.18^{*}$ & 0.24 & $3.35^{*}$ & 0.68 \\
\hline
\end{tabular}

- N.B:*means independent t-test, **means one-way ANOVA.

- Significancelevel at p value $\leq 0.05$

Table 7 revealed that there was highly statistically significant difference between students' total perception regarding e-learning problems, total perception regarding strategies of improvement and their age. While no statistically significant difference between students' gender, attending e-learning course and study variables.

\section{DISCUSSION}

Masoumi \& Lindstrom (2012) stated that, the increasing use of web technologies has changed the way learning in higher education institutions are conducted. The fast-changing learning environment entails responsiveness to e learning, and lots of studies are motivated to ascertain an efficient e-learning platform that meets students' needs (Chyung \& Vachon, 2013). Moreover, e-learning is established in education institutions to draw in students from everywhere around the world. To confirm the institution's competitiveness in offering learning resources to diverse clientele, it must develop an efficient e-learning platform (Steeg et al., 2015).

This study was conducted to assess the problems of e learning and strategies of improvements from the faculty students' point of view. Findings of this study were 
answering the research questions: what the problems of e-learning courses from the students' point of view are and what are the strategies of improvements for managing these problems from the students' point of view.

The findings of this study revealed that the highest percentage of problems perceived by students was associated with the e-learning system such as high cost perceived by nursing students for preparing good software within the e-learning style followed by difficulty of applying it in some courses that need practical skills. It might be because the implementation of the curricula within the e-learning system needs a financial and human cost. This is to adjust the infrastructure within the educational institutions and to supply laboratories with computers connected to the internet to accommodate the number of students and also the existence of a maintenance person on an ongoing basis. Also, the results of the study indicate that it's difficult to implement some practical courses within the e-learning system because they need highly skilled faculty members in using e-learning systems, and there are students who live in remote places where it is difficult to access the Internet and others other students does not have a computer in their homes, which makes the teaching process difficult.

The above study findings is congruent with Hasan \& Clement (2012); Yamani, (2014) \& Tarus et al., (2015) who reported that the bulk of nursing students had high perception with the insufficient investment in infrastructure and technological assistance, low internet bandwidth, inadequate policies and low technical skills which is considered major problems of e-learning.

This result contradicted with study done by AlAdwan \& Smedley (2013) who found that students' perceptions of online learning had positive impact on their teaching as it was enjoyable and easy to access and use.

The current study found other problems perceived by nursing students associated with administrative system as insufficient numbers of computers for students followed by lack of computer labs in proportion to the number of students. These findings can be because of the recent introduction of the e-learning system and also the increase within the number of students, which entails many obligations and financial burdens. This ends up in some shortage of computer laboratory equipments and lack of some services associated with the e-learning system and most of the allocated budget is spent on the establishment of recent buildings so as to soak up the increasing number of students. Matched with the above result, Al-Azawei Parslow \& Lundqvist, (2016) found another problem towards e-learning application related to students' perception that reflected on unavailability of computers. So, the budget of higher education is adequate but there's a requirement to allocate a particular financial fund to e-learning (Tarus et al., 2015).

Naveed et al., (2017) found that e-learning problems lies in the fact that high number of students were suffering from the unavailability of the suitable number of computers and computer labs that suit their numbers. While Rodny (2014) have reported that the technologyrelated barriers like technical infrastructure and technology support challenges as the dominant barriers.

The above results spot light on problems associated with academic staff like non-response of faculty members to the new type of learning followed by lack of ability and competence among faculty members to use elearning within the educational process. This result may be due to the large number of work that falls on the teacher, lack of incentives to use the e-learning system , burden from the teaching hours, activities and followingup the students and most faculty staff lack knowledge in such kinds of systems and wish training courses to know their benefits. In agreement with the study finding $\mathrm{Al} \mathrm{Al}$ Gamdi \& Al Samarji (2016) declared that the majority of faculty member encounter challenges when working with e-learning teaching without training. Stoffregen (2016) reported that there were different barriers associated with Instructor, especially on the e-Learning training skills because lack of those skills will affect significantly on the boldness of instructor within the use of technology and that they will attempt to escape from using it. In this respect Alkharang \& Ghinea, (2013) have argued that some faculty staff do not feel the importance of using e-learning within the educational process. Also Islam, Beer \& Slack (2015) reported that a bulk of instructors are not trained to troubleshoot, nor change passwords or course settings, never mind resolve emergency technical problems. Bingimlas (2019) reported that several recent studies indicate that numerous faculty members have both competence and confidence in using e-learning tools; however, they still make little or no use of those available technologies because they hardly have enough time. In this respect Islam, Beer \& Slack (2015) have argued that e-learning need competent instructor to motivate students, show empathy, resolve emergency problems and reply to emails rapidly

Result of this study also revealed that there was high perceived students strategies for improvement of e- 
learning problems like holding training courses for faculty members and on students to use e-learning. From the research point of view this finding indicates that students and academic staff were in a need for intensive training programs to reinforce user skills towards computer and e-learning technologies. Undoubtedly, lack of individual skills can negatively affect their intention to use e-learning. This finding goes with Cavus \& Zabadi, (2014); Al-Azawei \& Lundqvist, (2015) as they reported that the e-learning training programs affect learner outcome that leads to increase their satisfaction, easy use, intention to accept technology and improve user confidence in adopting with technology. Also, Al-Shboul, (2013); Al-Azawei, Parslow \& Lundqvist, (2016) reported that there's a desire to conduct training programs by any or all instructors so as to point out them the benefits of e-learning systems and the way to use these technologies and try to involve students in such experience. Khan et al., (2012) conclude that academic staff should have an obligation to implement e-learning so as to meet the goals of all students more easily and enjoyably.

Also, the study findings showed that another strategy is to establish a stable system for the periodic maintenance of computers, headsets, and laboratory tools. This shows the importance of providing trained maintenance technicians on a way to deal with the elearning system and solve its problems, like internet cut off, maintaining computers and its connections. The above study findings are congruent with Ssekakubo et al., (2011) \& Al-Shboul, (2013) who have argued that a successful implementation of any technology cannot be achieved without professional technical staff to line up and maintain it. In this respect Khan et al., (2012) \& Tarus et al., (2015) stated that preparation of professional staff should be a first step before launching a system.

Regarding nursing students' points of view of study variables and their personal characteristics the present study results showed that there was highly statistically significant difference between nursing students' age and study variables. This can be because of the students' young age and their need for training on the importance of e-learning and ways to deal with it. This was incongruent with Zamani, Esfizani \& Damanch (2016) who found no statistically significant difference between participants' age and e-learning problems. While Al Mutair, (2015); Islam, Beer \& Slack (2015) reported that there was no statistically significant difference between students' age and obstacles and opportunities of elearning.

\section{CONCLUSION}

The finding of this present study concludes that Nursing students found that the e-learning system was problematic in certain respect. While the lowest problems were related to academic faculty staff according to their students perspectives, also the best strategies of improvements from students' perspectives were offering training courses for faculty members and to the students regarding the use of e-learning and establishing a stable system for the periodic maintenance of computers, headsets, and laboratory tools.

\section{Recommendations}

- Faculty administration should design intensive educational program to faculty staff and nursing students to improve their competences about elearning system.

- Provide budget for establishing an integrated information technology infrastructure and elearning should be prioritized, along with other necessary requirements.

- Provide enough computers to suit the number of students and improve the Internet.

- There's need for well-furnished computer laboratories with internet facilities and other ICT equipment.

- Improving the infrastructure and its technical equipment so as to make the right conditions for teachers for his or her use of the e-learning system in teaching process.

- Preparing professional technical staff to keep up the e-learning equipment and support users.

- Allocating material and moral incentives for teachers to implement e-learning to encourage and make them responsive to the advantages of this type of education and its application.

- Study the effect of e-learning on nursing practice and technical skills of nursing students.

- Repeat the study on large sample size and in numerous educational institutions to facilitate generalization of results.

\section{Conflict of Interests}

The authors declare that they have no conflict of interest.

\section{ACKNOWLEDGEMENT}

The authors are thankful to the institutional authority for completion of the work. 


\section{REFERENCES}

Al Gamdi, M.A. \& Samarji, A. (2016). Perceived barriers towards e-Learning by faculty members at a recently established university in Saudi Arabia. International Journal of Information and Education Technology, 6(1), p.23.

Al Mutair, A. (2015). Clinical Nursing Teaching in Saudi Arabia Challenges and Suggested Solutions. Journal of Nursing Care, 4(5), pp 27-29.

Al-Adwan, A. \& Smedley, J. (2013). Exploring students acceptance of e-learning using Technology Acceptance Model in Jordanian universities. International Journal of Education and Development, 2(9), pp 4-18.

Al-Azawei, A. \& Lundqvist, K. (2015). Learner differences in perceived satisfaction of an online learning: An extension to the Technology Acceptance Model in an Arabic sample. Electronic Journal of E-Learning, 13(5), pp 408-426.

Al-Azawei, A., Parslow, P. \& Lundqvist, K. (2016). Barriers and opportunities of e-learning implementation in Iraq: A case of public universities. The International Review of Research in Open and Distributed Learning, 17(5).

Alkharang, M. M. \& Ghinea, G. (2013). E-learning in higher educational institutions in Kuwait: Experiences and challenges. Journal of Advanced Computer Science and Applications (IJACSA), 4(4), pp 3-5.

Allen, I. E. \& Seaman, J. (2014). Grade change: Tracking online education in the United States. Babson Survey Research Group. Newburyport, MA: Sloan Consortium. Pp:45

Al-Shboul, M. (2013). The level of e-learning integration at the University of Jordan: Challenges and opportunities. International Education Studies, 6(4), pp 93-113.

Anderson, A. (2018). Seven major challenges for e learning in developing countries: Case study EBIT, Sri Lanka. International Journal of Education and Development, 4(3).

Assareha, A. \& Hosseini, B.M. (2016). Barriers to e-teaching and e-learning, Procedia Computer Science. International Review of Research in Open and Distributed Learning, 17 (5), pp 127-146.

Barker, K., Omoni, G., Wakasiaka, S., Watiti, J., Mathai, M. \& Lavender, T. (2013). 'Moving with the times' taking a glocal approach: A qualitative study of African student nurse views of e learning. Nurse Education Today, 33(4), pp 407-412.

Bingimlas, K.A. (2009). Barriers to the successful integration of ICT in teaching and learning environments: A review of the literature. Eurasia Journal of Mathematics, Science and Technology Education, 5(3), pp.235-245.

Button. D., Harrington. A. \& Belan, I. (2016). E-learning \&amp; information communication technology (ICT) in nursing education: A review of the literature. Nurse Education Today, (10), pp 13-23.

Cavus, N. \& Zabadi, T. (2014). A comparison of open source learning management systems. Procedia Social and Behavioral Sciences, 143, pp 521-526.

Chapman, A. (2012). Future VLE Recommendation Report for Middlesex University, London. Middlesex University. Retrieved from: https://futurelearningtechnologies.wordpress.com/2012/01/25/future-vle-scoping-study-report/

Chen, C.C. \& Yang, S.C. (2014). The efficacy of online cooperative learning systems, the perspective of task-technology fit. Campus Wide Information Systems, 23(3).

Cheng, Y.M. (2011). Antecedents and consequences of e-learning acceptance. Information Systems Journal, 21(3), pp 269299.

Chyung, S. \& Vachon, M. (2013). An Investigation of the Profiles of Satisfying and Dissatisfying Factors in E-Learning. Performance Improvement Quarterly, 26(2), pp 117-140.

Donahue, N. \& Glodstein, S. (2013). Mentoring the needs of non traditional students. Teaching and Learning in Nursing, $8(1), \mathrm{pp} 2-3$.

Edwards, J. \& Connor, P.A. (2014). Improving Technological Competency in Nursing Students: The Passport Project. 
Journal of Educators Online, 8(2), pp1-20.

Egan, T.M. \& Akdere, M. (2004). Distance Learning Roles and Competencies: Exploring Similarities and Differences between Professional and Student Perspectives. Online Submission.

El-Hersh, A., Muflih., M. \& Aldhoon, M. (2010). Obstacles of the Application of E-Learning Systems as Viewed by faculty Teachers at AKurah District. Jordan Journal of Educational Sciences, 6(1), pp 27-40.

Hasan, S.H.M. \& Clement, C.K. (2012). Barriers to the introduction of ICT into education in developing countries: The example of Bangladesh. International Journal of Instruction, 5(2), pp 61-80.

Hogan, R. \& Kedrayate, A. (2015). E-learning: A Survival Strategy for Developing Countries. Social and Economic Studies, 60(3/4), pp 1-17.

Islam, N., Beer, M. \& Slack, F. (2015). E-Learning Challenges Faced by Academics in Higher Education. Journal of Education and Training Studies. 3(5), pp 102-112.

Jetté, S., Tribble, D.S.C., Gagnon, J. \& Mathieu, L. (2010). Nursing students' perceptions of their resources toward the development of competencies in nursing informatics. Nurse Education Today, 30(8), pp 742-746.

Keengwe, J. \& Kidd, T.T. (2010). Towards best practices in online learning and teaching in higher education. MERLOT Journal of Online Learning and Teaching, 6(2), pp 533-541.

Khan, S. H., Hasan, M. \& Clement, C. K. (2012). Barriers to the introduction of ICT into education in developing countries: The example of Bangladesh. International Journal of Instruction, 5(2), pp 61-80.

Koch, L.F. (2014). The nursing educator's role in e-learning: A literature review. Nurse Education Today, 34(11), pp 13821387.

Lakbla, P. (2016). Barriers in Implementing E-Learning in Hormozgan University of Medical Sciences. Global Journal of Health Science, 8(7), pp 83-92.

Macharia, J.K. \& Pelser, T.G. (2014). Key factors that influence the diffusion and infusion of information and communication technologies in Kenyan higher education. Studies in Higher Education, 39(4), pp 695-709.

Masoumi, D. \& Lindstrom, B. (2012). Quality in e-learning: a framework for promoting and assuring quality in virtual institutions. Journal of Computer Assisted Learning, 28(1), pp 27-41.

Mayer, B., Ring, C., Muche, R., Rothenbacher, D. \& Schmidt-Straßburger, U. (2015). Creating a blended learning module in an online master study Programme in oncology. Education for Health, 28(1), p.101.

Naveed, Q.N., Muhammed, A., Sanober, S., Qureshi, R.M. \& Shah, A. (2017). Barriers Effecting Successful Implementation of E-Learning in Saudi Arabian Universities. International Journal of Emerging Technologies in Learning (iJET), 12(6), pp 94-107.

Nhoun, O., X. Bhuasiri, J.J. \& Rho, H.Z. (2012). The critical success factors of e-learning in developing countries. Journal of Social Science, 33(5), pp 104-107.

Njenga, J.K. \& Fourie, L.C.H. (2017). The myths about e-learning in higher education. British. Journal of Educational Technology, 41(2), pp 199-212.

Nyerere, J.K., Gravenir, F.Q. \& Mse, G.S. (2012). Delivery of open, distance, and e-learning in Kenya. International Review of Research in Open and Distributed Learning, 13(3), pp 185-205.

O'Malley, B. (2007). Education under Attack: A Global Study on Targeted Political and Military Violence against Staff, Students, Teachers, Union and Government Officials, and Institutions. United Nations Educational, Scientific and Cultural Organization (UNESCO).

Opeyemi, O.Z., Adeyemi, A.A., Olajuwon, T.D., Nike, O. \& Oloruntosin, B.S.O. (2019). Perception of nursing students towards online learning: A case study of Lautech open and distance learning centre, Ogbomoso, Oyo State, Nigeria. 
Galore International Journal of Health Sciences and Research, 4(4), pp 23-30.

Oyo State, Nigeria. Galore International Journal of Health Sciences and Research, 4(4), pp 23-30.

Othman, O.H. (2016). Distance E-learning and Knowledge Society. Proceedings of the Eleventh International Conference: Learning in the Era of Digital Technology: The Center of Jil Scientific Research Center, Tripoli: Jil Scientific Research Center and the University of Tipasa, pp 79-92.

Pettersson, F. \& Olofsson, A. (2015). Implementing distance teaching at a large scale in medical education: a struggle between dominant and non-dominant teaching activities. Journal of Education and Information Technologies, 20 (2), pp 359-380.

Pourghaznein, T., Sabeghi, H. \& Shariatinejad, K. (2015). Effects of e-learning, lectures, and role playing on nursing. Medical Journal of the Islamic Republic of Iran (MJIRI), 29(1), pp 25-31.

Rasem, N.K. (2013). Promises and challenges. Journal of Educational Technology, 1(5), 11.

Rodny, S. (2014). The integration of instructional technology into public education: Promises and challenges. Journal of Educational Technology, 1(42), pp 5-13.

Sangra, A., Vlachopoulos, D. \& Cabrera, N. (2018). Building an Inclusive Definition of E-Learning:An Approach to the Conceptual Framework. The International Review of Research in Open and Distributed Learning, 13(2), pp 145-159.

Sayed, M. \& Baker, F. (2014). Blended Learning Barriers: An Investigation, Exposition and Solutions. Journal of Education and Practice, 5(6), pp 81-85.

Ssekakubo, G., Suleman, H. \& Marsden, G. (2011). Issues of adoption: have e-learning management systems fulfilled their potential in developing countries?. In Proceedings of the South African Institute of Computer Scientists and Information Technologists conference on knowledge, innovation and leadership in a diverse, multidisciplinary environment, pp 231-238.

Steeg, L., IJkema, R., Wagner, C. \& Langelaan, M. (2015). The effect of an e-learning course on nursing staff's knowledge of delirium: A before-and-after study. BMC medical education, 15(1), 12.

Stoffregen, J.D., Pawlowski, J.M., Ras, E., Tobias, E., Šćepanović, S., Fitzpatrick, D., Mehigan, T., Steffens, P., Przygoda, C., Schilling, P. \& Friedrich, H. (2016). Barriers to open e-learning in public administrations: A comparative case study of the European countries Luxembourg, Germany, Montenegro and Ireland. Technological Forecasting and Social Change, 111,pp.198-208.

Tarhini, A., Teo, T. \& Tarhini, T. (2016). A Cross-Cultural Validity of the E-Learning Acceptance Measure (ElAM) in Lebanon and England: A Confirmatory Factor Analysis. Journal of Education and Information Technologies, 21(5), pp 1269- 1282.

Tarus, J. K., Gichoya, D. \& Muumbo, A. (2015). Challenges of implementing e-learning in Kenya: A case of Kenyan public universities. International Review of Research in Open and Distributed Learning, 16(1), pp 120-141.

Williams, P.E. (2013). Roles and competencies for distance education programs in higher education institutions. The American Journal of Distance Education, 17(1), pp 45-57.

Yamani, H.A. (2014). E-learning in Saudi Arabia. Journal of Information Technology and Application in Education, 3(4), p 169.

Yom, Y. (2014). Interrelation of Internet-based learning and traditional face- to- face learning in an RN-BSN course. CIN: Computers, Informatics, Nursing, 22(3), pp145-52.

Zamani, B.E., Esfizani, A. \& Damanch, S.M.A. (2016). Major barriers for participating in online teaching in developing countries from Iranian faculty members' perspectives. Australasian Journal of Educational Technology, 32(3), pp 33-47. 